TEACHER EDUCATION: AN IMPERATIVE FOR NIGERIA'S VISION 2020

\author{
$\begin{array}{llll}\text { A. F. MOHAMMED A. E. ADENIYI G. UYAGU B. YAHYA } & \text { AHA }\end{array}$ \\ Dept. of Curriculum \& Instruction, Federal College of Education, Zaria, Nigeria \\ R. MOHAMMED \\ School of Education, Shehu Shagari College of Education, Sokoto, Nigeria
}

\begin{abstract}
The major focus of this paper is an examination of how teacher education can be used to respond to the Nigeria vision 2020 challenges which entails total development plan for the nation. More specifically, the paper examined how teacher education could partly helped in attaining the goal of vision 2020 in making the country economically prosperous, politically stable and socially harmonious. To achieve these objectives, the paper examined the concepts of national development, teacher education, its objectives and curricular and relate them to the issues of vision 2020. The paper suggested the need for teacher education programme to be improved upon within the context of vision 2020.
\end{abstract}

\title{
Introduction
}

Teacher education which is essentially the training and/or production of wellequipped teachers can be looked upon as comprising the production of pre- primary and secondary school teachers. Thus, teacher education refers to the structures, institutions and processes by means of which men and women are prepared for work in educational setting (Fafunwa, 1992). There is need to clarify this concept because this paper will focus on the type of teachers needed to the challenging of science of an emerging nation in view of the recent Nigeria vision 2020.

The success of any nation depends to a large extent on the quality of it education system, because it is this that will translate the dreams and aspirations of that nation into reality. The translation of ideas and values which a society believes in to a large extent cannot be accomplished without a quality teacher preparation by the educational system. It is often asserted that no system of education can be of high quality than that of its teachers. The teacher is central to the success of any teaching learning process. In fact proficiency as measured by pupil achievement has been shown to be largely a function of the teacher's mastery of the subject matter, use of the appropriate teaching - learning strategies and positive professional attitudes (Tatto, 1991 in Olaofe 2003a).

The main focus of this paper therefore, is an examination of how teacher education can respond to societal needs which guaranteed an economically prosperous, politically stable and socially harmonious dream of Nigeria's vision 2020 '. To attain this objective, the paper will examine the concept of national development, objectives of teacher education, Teacher education curricular and the issues of Vision 2020, and implication of teacher to the Vision 2020.

\section{National Development and Teacher Education}

It is important to clarify the use of the term national development-by pausing to consider the content, context and implication. This is necessary because it has attracted several definitions and usage. In general terms, development implies improvement of the welfare or well-being of her citizens. According to Nnachi and Nwana in Akpa and Khasar (2005) national development can be seen as growth plus 
changes which involve material, mental, psychological, physical, institutional and organizational innovations.

Because there are several concepts of development, one may wish to adopt operational definition which views development as the utilization and exploitation of resources (human and material) to improve the lot of members of a community, aimed at solving their most prominent problems (whether economic, social, political, environment, etc) without creating deliberately, new problem situation or backwashes within and without.

When therefore one consider the title of this paper teacher Education and national development within Nigeria Vision 2020, it is imperative to deliberate upon the extent to which the objectives, subject matter, learning experiences, modes, activities of those institutions which produced teachers are appropriate, efficient and effective in bringing about improvement (or maintain reasonable status quo) to the welfare of the people through the achievement of national goals and aspiration. It is therefore from this point of view that this paper will try to explore how the component of Teacher Education fit into the recent Nigeria vision 2020, in our dreams to realise our higher goals.

Teacher Education Objectives, Curriculum and the Issues of Nigeria Vision 2020 The National Policy on Education (2004) stated that the purpose of teacher education should mainly be to:

Produce highly motivated, conscious and efficient classroom teachers for all level of educations.

Encourage further the spirit of inquiry and creativity in teachers.

Help teachers fit into the social life of the community and society at large and to enhance their commitment to national objectives.

Produce teachers with the intellectual and professional background adequate for their assignment and to make them adaptable to any changing situation not only in the life of the country, but in the wider world.

\section{Enhance teachers' commitment to the teaching profession}

From the stated objectives of teacher education one can conclude that teachers must be well trained, flexible and willing to experiment and not be afraid of failure. But what are the implications of the curriculum? That is, what policy provision has been made to realise these teacher education objectives? To attain these objectives within national development or the current 'Vision 2020', one needs highly articulated teacher education curriculum. The curriculum which is the key to all education must be flexible enough to cope with the changing needs of the people and the country as well. In line with this, the National Policy on Education (2004) outlined the curriculum which teacher colleges (which produces the teachers for the primary and secondary levels) should seek to pursue and these are:

\section{General Studies (Basic Academic Subjects)}

Foundation studies (pedagogical knowledge and pedagogical content knowledge). Studies related to students chosen field of teaching (e.g. English, Social Studies, 
$\overline{\text { Integrated Science, Physical, Geography etc).These policy curriculum prescriptions }}$ have all long guided the details minimum standard document for the various teachers education programme in Nigeria. This is because teacher education are basically related to every phase of nation development and therefore, to have any meaningful development - be it in the social, economic or political sphere of activities, there is need to have highly competent and skilful teacher education programme. Furthermore, it is the teachers who give man education and education influences to a very large extent the course of action of that man, through whom development and changes are brought about. Since education is commensurate with life and as life progresses so those education for any meaningful progress therefore within the realm of education, the teachers who are the key agent in the process must be given quality training. In fact the recent scientific and technical advances and complexity of human life have necessitated the birth of new educational ideas and practices or and more democratic line. So for teachers to function properly, the programme prescribes for teachers education must be able to deal with the various demand of modern day requirement.

The question can be asked to what extent could the prescribe curriculum of the various teachers education programme be able to achieve the goals and aspirations of the nation and this paper, philosophy of 'vision 2020'? To answer this question, there is need to look into the concept and philosophy of 'vision 2020' and then relate them to issue of teachers education programme.

\section{Concept of Nigeria's Philosophy of Vision 2020}

The concept of development has to a large extent been globally defined, but what it means for a country is what the country has articulated in its policy statement, document, constitution and laws. Since the earliest days of history as a nation, steps have been taking to define a frame work for socio- economic development. In view of this, various development plans for the country were put in place (1962-1999) starting with first national development plan (1962-1968) which evolve the strategy of having and enduring foundation of national development.

But the Nigeria's national goals and aspiration as summarised in the second national development plan (1973-1976) document as well as in the suspended 1979 and 1989 constitutions - aimed at achieving post-war re-construction at the same time moved to enhance and boost the quality of life of the generality of the populace to chart a course for proper national development. All these developmental plans were unable to launch the nation on to her promise-land. In fact, the three -year rolling plans (1990-1992) introduced when the country adopted the Structural Adjustment Programme (SAP) in 1986 made a fundamental shift in planning strategy in the country. The regime of Abacha (1979) created distortions and in the end, the country was left with no clear vision or blue print for future development.

There is a strongly believe that the present shift from the national rolling plans might not be unconnected with our effort to harness the human and material resources available in the country. To articulate properly, the idea of vision 2020, the head of state of Nigeria inaugurated the vision 2020 committee with a 9-point terms of reference. These include: 
To define for the country, its correct bearing and sense of economic, political, social and cultural direction.

Examine all aspect of our national life which should be developed and fortified.

To set appropriate goals/target and time frame for achieving such economic, political, social and cultural objectives.

To propose the strategy and the institutional arrangement required to attain the set goals and targets.

To forge a plan which will ensure that Nigeria is en-route by the year 2020, to becoming a development in terms of economic prosperity, political stability and social harmony.

In particular, to focus on creating the right atmosphere and environment for sustainable annual growth of 6-10 percent of the Gross Domestic Product (GDP); the attainment of high literacy rate and qualitative education levels for the country.

It does not implied here that other areas of the committees assignment are no less important, but rather have tried to highlight the major aspect of the terms of reference which specifically deals with economy and subsequent nations development. The important of high literacy and qualitative education should of course be obvious. The education sector is relevant primarily to the nation's economic, social and political development and the key agent in this education sector is the teacher.

Discussion in this paper therefore, focused on the committee's terms of reference in relation to teacher education programme. Specifically, what are the correlates of these philosophical positions of government with the curriculum of the teacher education institutions in the country so as to bring about the needed development? Before one answers this question, there is the need to look against the objective of teacher education against number of militating factors in the society which could ever-shadow their realisation. The NPE 2004 states that, teacher education should produce highly motivated, efficient and conscious classroom teacher for all levels of our educational systems. In a situation where teachers have low salaries and as usual infrequent payment, this will not enhance the commitment of teachers to their work. More importantly, supervision in primary and secondary schools is ineffectively carried out a times. In fact in some instances no effective supervision whatsoever is carried out at the tertiary level of education.

Furthermore, the policy stated that teacher education should encourage further the spirit of inquiry and creativity among the teachers. The problem here is that the curriculum during training is followed rigidly and mode of assessment/evaluation encourages rote learning. Also teachers in training have access to limited or none at all of teaching materials and laboratories. These are further compounded with overcrowded classes. In this type of situation, one could not expect the teachers to develop the spirit of inquiry and creativity in their learners.

The objective that stresses the commitment of teachers to national objective can hardly be attained. This is because there are colleges without adequate libraries, laboratories and functional equipment which are imperative to intellectualism. Coupled to this, is that teachers are poor, infrequently paid and do not consider teaching a profession. 
It should be clear by now that the future desired position cannot be devoured from the effective ways by which it can be brought about. Thus, in teacher education, the strategic plans and actions that are designed to achieve future desired position must not be in conflict with those processes of its implementation. From the above analysis carried out, one could see that there are conflicts between the desired future positions and the processes of its implementation in which our minds will not lead to adequate attainment of these objectives. But Tahir (2001) states that we fail to situate these perceived problems within the nexus of the larger social transformation with a view to develop possibilities synergistic actions in the best interest of teacher education in Nigeria.

Therefore there is a need to necessarily situate the problems of education, especially that teacher education, within the political economy perspective. This anchored on the belief that education (teacher education) is not independent (non- relative autonomy) of politics and economics of the wider society.

\section{Teacher Education Curriculum and its Implication for Vision 2020}

There is the need to reiterate that teacher education is ultimately related to the ever recurring problems of the need for trained manpower in Nigeria and therefore affect those social, political and economic spheres of ours. In fact, teaching, more than any other profession that touches the life of practically every citizen (Fafunwa, 1992). This situation to our mind can hardly be attained without competent teachers throughout the entire educational system which is expected to produce the required manpower needed in the society. At these stage of our discussion, there is need to revisit the major components of teacher education curriculum presented earlier with a view to ascertain the possibility of attaining the philosophy behind Nigeria vision 2020 and if possible charting a new direction which will aligned with Nigeria vision 2020. Looking into the curriculum of teacher education, there is need to proffer answers to some crucial questions such as what sort of society do we aspire to build? What type of nation does government want for future generation? And more importantly, what the nation should become by the year 2020. There is need to be pondered upon and satisfactory answer given.

Based on the above questions, in order to answer them, the teacher education curriculum must first be structured towards realising these objectives. Firstly, the issue of general studies course undertaken during the teacher training becomes imperative. The philosophy behind general studies is that it is a course that will be undertaken by all students irrespective of their discipline of specialization which is designed to broaden their perspective in a world of rapid change, knowledge explosion, and increasing independent. The present situation shows that some institutions have interpreted it. Therefore, in line with vision 2020 enhancing qualitative levels in education, it is suggested that every general studies programmes should be design as to give maximum broadening of perspective. In this regards, general studies programmes for students in faculties and colleges of education should emphasis areas like element of environmental education, population education (which is presently being introduced as education course in colleges of education), consumer education, drug abuse education, computer education, this concept could lead to addressing contemporary problems of modern society. 
Secondly, the studies related to the student intended field of teaching. This is the training that will provide the would-be teacher with the necessary intellectual professional skills adequate for his assignment and also make him adoptable to any changing situation. More importantly, the training is oriented towards solving relevant problems of the society and its environs. But one major problem which is variously acknowledge by most literature on teacher education in Nigeria is that teachers trained are not sufficiently prepared in other to meet the complex demand of social, economic and technological advancement (Olaofe, 2003b). This situation will hardly allow the attainment of the national objectives not to mention the vision 2020. For teacher education curriculum contents to be relevant and meaningful in the realization of Nigeria vision 2020, the curriculum (which is the key to all education), teacher education must be flexible enough to cope with the changing needs of the people and the country. In fact, teacher education curriculum should keep pace with social, economic and technological advancement. Therefore, teacher education programmes must of necessity be adequately planned as an integral part of national development.

Thirdly, the practical teaching which forms another component of teacher education programme, emphasis the need to produce professional teacher with regards to teachers who can underpin their practice with relevant theory and make a responsible decision according to how they estimate the learning situations. But due to some reasons earlier highlighted, the teaching practice programme emphasis with the preparation of a functionary teacher. As a functionary teacher, the teacher is subjected to carryout prescription such as syllabus, scheme of work and the curriculum in general. His involvement in this task is minimal because it is reduce to carrying out instruction. Such a teacher finds it hard to cope with new teaching skills and the learning theories underlying them. In fact, he cannot fully implement new curricular because his preparation has been in deficient. This notwithstanding there is a number of practicing teachers without teaching qualification and sadly they too do not have zeal and urge towards occupational improvement.

From the above analysis, the question to ask is what is the relevant of teacher education to vision 2020? It has been earlier indicated that the relevance of teacher education to national development can be seen in term of provision of skilled manpower. The rapid advancement in the acquisition of knowledge of the natural science and mathematics and more especially in the technical application of knowledge is a function of calibre of teaching staff available. Therefore, the process of achieving a respectable level of social, political, cultural and economic development by the year 2020 will hardly by possible if effort are not geared towards a very functional teacher education programmes which will prepared best qualified, best motivated and women to enter the various sectors of the nations development move. It follows therefore that teacher education will continue to be very relevant in the development of the nation

Furthermore, the desirability of training vocational and technical skills and indeed the over- all problem of preparing the future citizens of the country who will be fully oriented to developmental effort cannot be affectively accomplished without the aid of competent teachers; neither can the economy to achieve the envisaged growth rate of $6-10 \%$ per annum between now and the year 2020. More importantly, the trained manpower cannot adequately meet the demand without proper articulation of teacher education programme designed for those purposes. 
In recent time, most society looks on formal education as a tool for achieving their national or societal goal. Bloom (1966) strongly observed that 'education is looked upon for solutions to problems of poverty, discord, crime, and delinquency, urban living, peace and even problems arising from affluence. 'Nigeria cannot be exception. If the masses must take a lively active and appreciative interest in development, and also make their own contributions to the social and economic advancement of the country and the rising of their general standard of living as envisage by vision 2020 , they must be educated. This job cannot be done by anyone other than the teacher; and unless the teachers go along with any new ideas, effort at reforming the country bound is to fail. In fact, teacher must understand and prepared to accept changing direction of the country.

It is equally hoped that the principle of social harmony envisaged by vision 2020 would hardly be attained with the present situations if adequate steps are not taken to train individuals as members of a community and of a nation. Teacher education if properly implemented could be used to train an individual's as a citizen and more importantly as tools of a national unity. There could hardly be any meaningful progress if young men and women are only intellectually and vocationally trained but are not taught to be true citizens not only of this nation but also of the world. It is only when this is achieved can then be a way forward towards achieving vision 2020 .

\section{Conclusion}

The year 2020 may seem to be far away but it is simply 5 years to come. Perhaps, vision 2020 could be a road map to future, but in a situation where there is prolonged political instability, intense ethnic rivalries, insecurity, corruption and conflict, bureaucracy, occasioned by repressive international economic environment that translates itself in term of unfair international trade patterns, heavy external debt burden and decline in resource net flow, no amount of resilience can make education especially teacher education, function sanely.

In fact there are still the some nations that allow ethnic and sectional considerations or supplant rational economic decisions. But there is a strong belief that vision 2020 if properly planned and coordinated within the programme of teacher education could lead to our desire for scientific and technological development. Our hope for making the best of what is available lies substantially in improving the quality of the teaching force, and aptitude for teaching. Because the changes needed in the nation cannot be adequately implemented without quality and competent teachers; and also the time is very short, perhaps too much shorter than can be imagined and this could hamper the future of the nations' development to be at stake. 


\section{References}

Abacha, S. (1997). Vision 2020: Long term plan to shape Nigeria destiny' speech at the inauguration of Vision 2020 Committee in Abuja Nigeria.

Akpa, A. \& Khasar, J. I. (2005). Vocational Technical Education in Nigeria in the $21^{\text {st }}$ Century. Katsina-Ala: SVTE Katsina-Ala Educational Series.

Bloom, B. (1966). ' Stability and change' in Human characteristic and school learning.

Fafunwa, B.A. (1992). ' The purpose of teacher Education' in Adaralegbe (ed) $A$ philosophy of Nigeria education_ report of the Nigeria curriculum conference, 8-12 September 1969, Ibadan, Heinemann Books Nigeria.

Federal Republic of Nigeria (2004). National policy on Education Lagos: Federal Ministry of information.

Olaofe, I. A. (2003). The Role of Language Education in the Implementation of the U.B.E. Programme, U.B.E. Forum No. 3.

Tahir, G. (2001). Federal Government Intervention in the U.B.E. Forum, 1. 